\title{
THE ADVANCEMENT OF ZAKAT INSTITUTION IN MALAYSIAN POST ISLAMIC REVIVALISM ERA
}

\author{
Suhaili Sarif", Nor Aini Ali** \& Nor 'Azzah Kamri***
}

\begin{abstract}
Zakat is an important Islamic institution in Malaysia. The development of the institution has been through time influenced by the changing social, political and economic situation of the country. One of the important phenomena that shaped the institution is the Islamization process which happened during Islamic revivalism which ushered in the early 1970s. The scenario and the social change that happened during the era have resulted in the zakat has been one of the institutions which government keened to enhance in the later decades. This article discusses the brief development of zakat institution in post Malaysian Islamic revivalism era, through which eventually, the impact of the revivalism on the institution will be clearly observed. As has been self-evident throughout the discussion, supported by the data of collection over the years, the zakat institution, apart from its fundamental role as religious duty, has been through time playing a greater role in social and economy.
\end{abstract}

Keywords: Zakat, Revivalism, Islamization, Malaysia, Islamic institution.

\section{Introduction}

Zakat is one of the important Islamic institutions in Malaysia. Zakat is theoretically a religious duty whereby Muslims compulsorily surrender part of their wealth to the eligible recipients. The duty has been institutionalized since collection of the payment was initiated by government as early as the 20th century. Prior to that time, zakat was a purely personal matter, the proceeds of which were mostly directed towards eligible recipients based on personal preference. ${ }^{1}$ The process of incorporating the religious practice under state administration began as early as 1916 in Kelantan, followed by the adoption of similar systems in other states such as Perlis in 1930, Johor in 1934, Kedah in 1936, Selangor in 1952, Pahang in 1956, Pulau Pinang and Melaka in 1959 and Federal Territory in 1974. ${ }^{2}$

The development from the early $20^{\text {th }}$ century until the end of the 1980 s was unsatisfactory. Revenue collected in this phase was mainly from two sources; zakat al-fitr, the due that the majority of people had long since performed without fail, and also zakat on cereal (particularly unhusked rice). ${ }^{3}$ Contributions from other types of wealth were relatively inconspicuous.

The zakat institution in Malaysia changed tremendously after post Islamic revivalism era, through corporatization in the 1990s and has been continuously improved since then. As compared to previous decades, this period saw the most significant advancement since the tradition was placed under state administration in the early 20th century. Prior to decade, the Malaysian government had introduced Islamization policies that countered political attacks from the opposition parties and missionary groups.

\footnotetext{
${ }^{*}$ Suhaili Sarif, Senior Lecturer, Department of Shariah and Management, Academy of Islamic Studies, University of Malaya, Kuala Lumpur, Malaysia.Email: suhaili@um.edu.my.

${ }^{* *}$ Nor Aini Ali (Corresponding Author), Senior Lecturer, Department of Shariah and Economics, Academy of Islamic Studies, University of Malaya, Kuala Lumpur, Malaysia. Email: aini@um.edu.my.

*** Nor 'Azzah Kamri, Senior Lecturer, Department of Shariah and Management, Academy of Islamic Studies, University of Malaya, Kuala Lumpur, Malaysia. Email: azzah@um.edu.my.

${ }^{1}$ Abdul Aziz bin Muhammad (1993), Zakat and Rural Development in Malaysia, Kuala Lumpur: Berita Publishing, pp. 110-111; Judith Nagata (1982), "Islamic Revival and the Problem of Legitimacy Among Rural Religious Elites in Malaysia," Man, Vol. 1, No. 17, p. 52.

${ }^{2}$ For further discussion about the history of the advent of zakat institution please refer Ahmad Ibrahim (1965), Islamic Law in Malaya, Singapore: Malaysian Sociological Research Institute Ltd., pp. 335-349; Moshe Yegar (1979), Islam and Islamic Institutions in British Malaya: Policies and Implementation, The Hebrew University, Jerusalem: Magnes Press, pp. 216-222; Azhar Mohd Nasir (1999), Development of the Secular and Religious Taxation System in Peninsular Malaysia, Doctoral Thesis, University of Edinburgh, pp. $207-252$. 3 Aidit bin Ghazali (1991), "Zakat Administration in Malaysia," in Mohamed Ariff (ed.), The Islamic Voluntary Sector in Southeast Asia, Singapore: Institute of Southeast Asian Studies, p. 95; Aidit Ghazali (1988), Zakat, Satu Tinjauan, Petaling Jaya: IBS Buku, pp. 48-49.
} 
Such policies, interestingly, have to a certain extent resulted in the improvement of the zakat institution, yet full deliberation on the linkage between both has never been brought into focus.

\section{Islamic Revivalism and Islamization Scenario in Malaysia: Forces and Consequences}

The Islamic revivalism in Malaysia from the early 1970s was indicated by the proliferation of missionary groups such as Angkatan Belia Islam Malaysia (Islamic Youth Movement of Malaysia or ABIM), Jamaat Tabligh and Darul Arqam. ${ }^{4}$ This era has ignited a distinct scenario which is widely known as Islamization. Islamization in this context refers to a process by which Islamic culture and values become embedded in society due to mushrooming religious groups which instil Islamic values at the societal level, beginning within the individual and later emerging in the Islamic family and then in Islamic society. ${ }^{5}$

ABIM was established in 1971 by several alumni of the National Association of Malaysian Islamic Students, which mainly provided rooms for graduates and young professionals who had been active in university student associations. ${ }^{6}$ Another two movements were more apolitical in nature. Darul Arqam - named after a prophet companion- was established in 1968 under Ashaari Muhammad. ${ }^{7}$ While, Jamaat Tabligh, another well-known association, was a missionary movement working at a grassroots community level by making local mosques their makeshift headquarters, normally consisting of up to ten, conducted gasht (visits) to local Muslims on a door-to-door basis. They would explain the essentials of the faith to each host and issue invitations to the daily prayer congregation in the nearest mosque, where further sessions of ta 'lim (imparting of knowledge) and bayan (lectures on the necessity and nature of the Tabligh's work) would be delivered. ${ }^{8}$

Since their formation, the movements have received strong support, mainly from youth in higher educational institutions, where both have strong connections and similar aspirations. ${ }^{9}$ It was estimated that in 1980 the ABIM had 35,000 registered members throughout the nation, while Darul Arqam had approximately 6,000 members. Responding to the local political situation, the movements, with remarkably strong support from their thousands of members, demanded a clear promise of a completely Islamic state, a demand that the ruling government could not leave unanswered. ${ }^{10}$

In reaction to the then political developments, the government, in the early 1980s- perhaps this time can be argued as a beginning of post Islamic revivalism era- embarked on numerous Islamization programs. This move was important in showing that the ruling government was highly Islamic so that it could attract devout Muslims and drive out the opposition. The Islamization programs initiated by the government included the expansion and strengthened capacity of a number of Islamic institutions such as Pusat Islam (Islamic Centre), the Institute of Islamic Understanding Malaysia, the Islamic International University of Malaysia and many others including the zakat institution.

\section{Corporatization - A Trajectory Point of Zakat Management in Post Islamic Revivalism Era}

The first concrete effort towards better management of zakat during the post Islamic revivalism era was begun in 1991 by the introduction zakat corporatization. The concept of zakat corporatization was the brainchild of former Chief Minister of the state of Pahang, with strong support from Mohd Yusof Noor, the then Minister overseeing religious affairs in the Prime Minister's Department. In view of the fact

\footnotetext{
${ }^{4}$ Mohamad Abu Bakar (1981), "Islamic Revivalism and Politics in Malaysia”, Asian Survey, Vol. 10, No. 21, pp. 1040-1041; Jomo K.Sundaram and Ahmad Shabery Cheek (1988), "The Politics of Malaysia's Islamic Resurgence” Third World Quarterly, Vol. 2, No. 10, pp. 844-848; Judith Nagata (1980), "Religious Ideology and Social Change: The Islamic Revival in Malaysia", Pacific Affairs, Vol. 53, No. 3, pp. 417-428.

${ }^{5}$ Muhammad Syukri Salleh (1994), "Islamization of State and Society: A Critical Comment", Noraini Othman (ed), Sharia Law and the Modern Nation State, Kuala Lumpur: Sister in Islam, p. 110; William R. Roff (1998), "Pattern of Islamization in Malaysia, 1890s-1990s: Exemplars, Institutions and Vectors", Journal of Islamic Studies, Vol. 9, No. 2, p. 220.

${ }^{6}$ Judith Nagata, "Religious Ideology and Social Change: The Islamic Revival in Malaysia", p. 424.

${ }^{7}$ Ahmad Fauzi Abdul Hamid (1998), "Islamic Resurgence in the Periphery: A Study of Political Islam in Contemporary Malaysia with Special Reference to the Darul Arqam Movement", Phd Thesis, University of Newcastle Upon Tyne; Zainah Anwar (1987), Islamic Revivalism in Malaysia: Dakwah Among Students, Petaling Jaya: Pelanduk Publication, p. 36.

${ }^{8}$ Ahmad Fauzi Abdul Hamid (2009), "Transnational Islam in Malaysia" in Transnational Islam in South and Southeast Asia; Movements, Networks and Conflicts Dynamics, USA: The National Bureau of Asian Research, p. 154.

${ }^{9}$ Jomo K.Sundaram and Ahmad Shabery Cheek (1988), “The Politics of Malaysia's Islamic Resurgence,” Third World Quarterly, Vol. 2, No. 10, p. 845; Judith Nagata (1980), "Religious Ideology and Social Change: The Islamic Revival in Malaysia,” p. 423.

${ }^{10}$ Jomo K.Sundaram and Ahmad Shabery Cheek (1988), "The Politics of Malaysia's Islamic Resurgence," p. 846.
} 
that Mohd Yusof was one of the religious individuals co-opted by the government to accelerate its Islamization agenda, it seemed that the earlier step had undeniably paid off.

Corporatization is a new model of zakat collection, achieved through the establishment of a company or corporate organization which manages the due, replacing the traditional personal zakat collector ('amil) and direct administration by State Religious Councils. A corporate zakat collector, being a company or organization, is responsible for the complete range of activities such as planning, organizational setup, hiring and training staff, setting up offices and counters, software development and computerized systems, and annual and monthly reporting, as well as being accountable for all costs and activities involved in zakat collection. ${ }^{11}$

The performance of the new institution under the name of Zakat Collection Center of Federal Territory (Pusat Pungutan Zakat, hereafter referred as PPZ) has indeed been encouraging. Since its inception, the meteoric increase in the collection has exceeded expectations, more than doubling in the first year and rising consistently since then. The collection records from its inception through 2016 (in five-year intervals over 25-year period) are as indicated in the table below.

Table 1: Zakat Collection in Federal Territory in five-year intervals from 1991 to 2016 (in Million RM) ${ }^{12}$

\begin{tabular}{cc}
\hline Year & Total Zakat Collection \\
\hline 1991 & 14.64 \\
1996 & 42.92 \\
2001 & 72.87 \\
2006 & 147.59 \\
2011 & 348.88 \\
2016 & 580.69 \\
\hline
\end{tabular}

The corporatization of the zakat administration in Federal Territory has inspired other states to follow suit. Corporatization was seen to be more suitable on at least two counts: increasing zakat collection and retention of the institution under individual state power. The PPZ received numerous group visits from other state religious councils who were curious about the new mechanism of collection, and thus became the main reference point for states interested in improving their zakat institutions. Consequently Penang, Selangor and Pahang ended by adopting a similar model a few years later. ${ }^{13}$ Today, majority of states have their own corporate zakat institution.

\section{Methodology}

In order to examine the impact of Islamic revivalism and Islamization process on Malaysian zakat institution, the development of the institution is retrospectively examined. In this context, the previous studies in relation to Islamic revivalism and zakat institution as well as records of fund collection and distribution are reviewed and compared over time. Such a research design allows the researchers to look backwards and examine any possible underlying factors and effect on zakat which can be associated with the revivalism and Islamization phenomenon, the main contributing agent in the study. From the observation of several trajectorial events and significant surge in fund collection and distribution after corporatization of zakat institution, there are some answers can be derived which encompass financial and non-financial aspects.

\footnotetext{
${ }^{11}$ Pusat Pungutan Zakat - Majlis Agama Islam Wilayah Persekutuan (2003), Laporan Zakat 2003, Kuala Lumpur: Pusat Pungutan Zakat Majlis Agama Islam Wilayah Persekutuan, p. 45.

12 Pusat Pungutan Zakat - Majlis Agama Islam Wilayah Persekutuan (2002), Laporan Zakat 2002, Kuala Lumpur: Pusat Pungutan Zakat Majlis Agama Islam Wilayah Persekutuan, p. 4; Pusat Pungutan Zakat - Majlis Agama Islam Wilayah Persekutuan (2011), Laporan Zakat 2011, Kuala Lumpur: Pusat Pungutan Zakat - Majlis Agama Islam Wilayah Persekutuan, p. 97; Pusat Pungutan Zakat - Majlis Agama Islam Wilayah Persekutuan (2016), Ringkasan Laporan Zakat 2016, Kuala Lumpur: Pusat Pungutan Zakat - Majlis Agama Islam Wilayah Persekutuan, p. 3.

${ }^{13}$ Harian Metro (1992), "Pungutan Zakat WP Menjadi Contoh,” 21 January; In 1994, Penang has adopted a similar system where PPZ was appointed as its consulting firm. The other states gradually follow suit with some of them have more or less similar systems. See also Ab Rahim Zakaria (2007), "Pengurusan Zakat Kontemporari,” Jurnal Pengurusan JWZH, Vol. 1, No. 1, p. 16.
} 


\section{The Advancement of Zakat Institution in the Post Islamic Revivalism Era}

Among the impacts of corporatization and improvement of zakat are as follow:

\section{Improvement in Zakat Management and Better Collection}

As noted, a number of states have emulated the corporatization of PPZ. Similar to the PPZ's achievement, the collection of zakat by later corporatized institutions was also remarkable. The overall performance by these bodies is simplified in the table below, which indicates their pre- and postcorporatization records.

Table 2: Corporatization in Malaysia and Pre- and Post-Corporatization Collection ${ }^{14}$

\begin{tabular}{lccc}
\hline State & $\begin{array}{c}\text { Corporatization } \\
\text { Date }\end{array}$ & $\begin{array}{c}\text { Pre-Corporatization } \\
\text { Collection (Mill RM) }\end{array}$ & $\begin{array}{c}\text { Post-Corporatization } \\
\text { Collection (Mill RM) }\end{array}$ \\
\hline Federal & December 1990 & $7(1990)$ & $15(1991)$ \\
Territory & & & \\
Penang & December 1994 & $4.05(1994)$ & $7.09(1995)$ \\
Selangor & October 1995 & $13.1(1995)$ & $27.9(1996)$ \\
Pahang & January 1996 & $7.16(1996)$ & $8.3(1997)$ \\
Melaka & September 2000 & $8.43(2000)$ & $12.03(2001)$ \\
Negeri & January 2000 & $8.76(1999)$ & $10.62(2000)$ \\
Sembilan & & $16.65(2006)$ & $17.51(2007)$ \\
Sabah & January 2007 & & \\
\hline
\end{tabular}

A few years after corporatization in Federal Territory, as demonstrated in the above table, six other states followed suit, clearly showing that the 1990s were the transformational decade for the zakat institution in these states. As a result, the new mechanism has led to the constant increment of zakat collection throughout the country since then. In 2015, the collection figure is reaching more than RM 2.3 billion, a tremendous jump from the barely-achieved RM 30 million annually at the end of the 1980 s. $^{15}$

\section{Coordination between the States}

Federal government over time has seemed interested in centralizing the collection although administratively, as earlier noted, the institution is under the respective states' jurisdiction. In this regard, the Minister of Finance, and Ministers in the Prime Minister's Department, have frequently voiced the government's aspiration to coordinate the fund management. ${ }^{16}$ The Minister of Finance, for example, announced in 1992 that the Internal Revenue Department, the federal department collecting taxation, should be the sole national zakat collector. ${ }^{17}$

A further proposal was made in 2000, when a Minister in the Prime Minister's Department suggested that the fund should be not only centrally collected but also centrally disbursed. In this case, the Malaysian Zakat Management Board was recommended. Neither of these two suggestions, however, has yet been successfully implemented, as there has been no solid agreement from the states to relinquish their power to the federal government. ${ }^{18}$

Since proposals for collective management were not positively responded to by all the states, the federal government clearly understood that it would be better to support the institution indirectly through consultation and coordination. In this respect, the government established Jabatan Wakaf, Zakat dan

\footnotetext{
${ }^{14}$ Ab Rahim Zakaria (2007), "Pengurusan Zakat Kontemporari,” p. 16; Sanep Ahmad et al. (2006), "Penswastaan Institusi Zakat dan Kesannya Terhadap Pembayaran Secara Formal Di Malaysia," International Journal of Management Studies, Vol. 13, No. 2, p. 179; Pusat Pungutan Zakat - Majlis Agama Islam Wilayah Persekutuan (2002), Laporan Zakat 2002, Kuala Lumpur: Pusat Pungutan Zakat - Majlis Agama Islam Wilayah Persekutuan, p. 4; Jabatan Wakaf, Zakat dan Haji (2019), "Statistik Agihan Zakat," retrieved 20 $0^{\text {th }}$ March 2019, http://baitulmal.jawhar.gov.my/zkt_agihan_stat.php.

${ }^{15}$ Pusat Pungutan Zakat - Majlis Agama Islam Wilayah Persekutuan (2016), Laporan Zakat 2016, Kuala Lumpur: Pusat Pungutan Zakat Majlis Agama Islam Wilayah Persekutuan, p. 91

16 Azhar Mohd Nasir (1999), "Development of the Secular and Religious Taxation System in Peninsular Malaysia," pp. 277-288; Kikue Hamayotsu (2004), "Islamisation, Patronage and Political Ascendancy, The Politics and Business of Islam in Malaysia," in Edmund Terence Gomez (ed.), The State of Malaysia, Ethnicity, Equity and Reform, London: Routledge Curzon, pp. 231-234.

${ }^{17}$ Azhar Mohd Nasir (1999), "Development of the Secular and Religious Taxation System in Peninsular Malaysia," p. 334; The Sun (1996), "Special Agency to Collect Zakat from Firms," 16 October.

${ }^{18}$ Kikue Hamayotsu (2004), "Islamisation, Patronage and Political Ascendancy," p. 232.
} 
Haji (Department of Awqaf, Zakat and Hajj or JAWHAR) in 2004. Its inception was specifically designed to accelerate the development of the zakat, waqf and hajj institutions, which up to then had been among the roles played by the Department of Islamic Development Malaysia (JAKIM). The part played by the department until recently has mainly been in the form of intellectual discourse and the organization of various seminars and publications as well as research. ${ }^{19}$ The new department has successfully helped the institution in a number of ways. It has embarked on a number of researches into zakat practice throughout the country. It has also produced a comprehensive guideline for fund distribution, making it a main reference for all zakat bodies. ${ }^{20}$ By and large, with other achievements contributing to the overall development of the zakat institution, the department indeed deserves recognition.

\section{Greater Role in Poverty Eradication}

In addition to the two effects described previously, the growth in collection posed a challenge to the zakat institution to distribute the fund more effectively. As far as the disbursement aspect is concerned, the greater portion has gone to poverty eradication. The general trend of disbursement following corporatization can be observed in the following tables.

Table 3: Zakat Disbursement by State in 2000 (in Million RM) ${ }^{21}$

\begin{tabular}{|c|c|c|c|c|c|c|c|c|}
\hline State & Miskin & Faqir & 'Amil & Mu'allaf & $\begin{array}{c}\text { Ibn al- } \\
\text { Sabil }\end{array}$ & $\begin{array}{c}F i \\
\text { Sabilillah }\end{array}$ & Gharimin & Riqab \\
\hline $\begin{array}{l}\text { Federal } \\
\text { Territory }\end{array}$ & 11.75 & 3.75 & 8.16 & 0.91 & 0.11 & 20.5 & 0.32 & - \\
\hline Selangor & 4.34 & 1.99 & 4.37 & 2.15 & 0.12 & 12.8 & 1.46 & - \\
\hline Penang & 2.21 & 0.75 & 2.35 & 0.27 & 0.05 & 5.31 & 1.01 & - \\
\hline $\begin{array}{l}\text { Negeri } \\
\text { Sembilan }\end{array}$ & \multicolumn{2}{|c|}{1.66} & 1.24 & 0.66 & 0.06 & 1.59 & 3.86 & - \\
\hline Melaka & 1.42 & 2.11 & 1.16 & 0.42 & 0.06 & 1.83 & - & - \\
\hline Sabah & 1.07 & 0.08 & 0.34 & 0.02 & - & - & - & - \\
\hline Kelantan & \multicolumn{2}{|c|}{2.8} & 1.05 & 0.3 & 0.09 & 5.54 & 0.01 & \\
\hline Terengganu & 7.05 & 2.6 & 0.87 & 0.49 & 0.06 & 1.97 & 0.23 & 0.02 \\
\hline Perlis & 1.01 & 0.31 & 0.93 & 0.16 & 0.01 & 2.93 & . & - \\
\hline Kedah & \multicolumn{2}{|c|}{4.62} & 0.77 & 0.26 & 0.07 & 2.06 & 0.02 & - \\
\hline Perak & \multirow{2}{*}{\multicolumn{2}{|c|}{6.47}} & 1.62 & 1.24 & 0.28 & 6.44 & 0.21 & - \\
\hline Johor & & 4.65 & 4.83 & 2.01 & 0.03 & 10.8 & 0.12 & - \\
\hline
\end{tabular}

Table 4: Zakat Disbursement by State in 2008 (in Million RM) ${ }^{22}$

\begin{tabular}{lcccccccc}
\hline State & Miskin & Faqir & 'Amil & Mu'allaf & $\begin{array}{c}\text { Ibn al- } \\
\text { Sabil }\end{array}$ & $\begin{array}{c}F i \\
\text { Sabilillah }\end{array}$ & Gharimin & Riqab \\
\hline Federal & 20.51 & 22.67 & 31.64 & 5.65 & 0.4 & 85.04 & 1.65 & - \\
Territory & & & & & & & & \\
Selangor & 51.17 & 11.39 & 30.39 & 11.67 & 0.69 & 63.6 & 18.98 & 1.08 \\
Penang & 2.19 & 20.3 & 5.45 & 0.76 & 0.14 & 15.72 & 1.02 & - \\
Negeri & \multicolumn{2}{c}{12.24} & 4.68 & 2.67 & 0.27 & 6.05 & 1.37 & 9.53 \\
Sembilan & & & & & & & & \\
Melaka & 6.21 & 1.17 & 4.25 & 1.42 & 0.006 & 7.64 & 0.012 & - \\
Sabah & 4.56 & 6.58 & 2.47 & 1.53 & 0.020 & 4.17 & 0.0004 & - \\
Kelantan & 10.11 & 9.56 & 1.78 & 0.79 & 0.003 & 3.04 & 0.012 & - \\
Terengganu & 13.54 & 3.24 & 9.42 & 1.05 & 0.013 & 8.2 & 0.06 & 0.15 \\
Perlis & 4.08 & 0.84 & 1.38 & 0.18 & 0.004 & 9.35 & 0.005 & - \\
Kedah & 17.62 & 1.85 & 5.841 & 1.01 & 0.22 & 15.59 & 0.002 & - \\
Perak & 19.19 & 6.4 & 1.82 & 0.46 & 9.07 & 0.13 & - \\
\hline
\end{tabular}

\footnotetext{
${ }^{19}$ Ab Rahim Zakaria (2007), "Pengurusan Zakat Kontemporari," p. 20.

${ }^{20}$ Jabatan Wakaf, Zakat dan Haji (2007), Manual Pengurusan Agihan Zakat, Putrajaya: Jabatan Wakaf, Zakat dan Haji.

${ }^{21}$ Pusat Pungutan Zakat - Majlis Agama Islam Wilayah Persekutuan (2001), Laporan Zakat 2000-2001, Kuala Lumpur: Pusat Pungutan Zakat - Majlis Agama Islam Wilayah Persekutuan, p. 78-84.

${ }^{22}$ Pusat Pungutan Zakat - Majlis Agama Islam Wilayah Persekutuan (2008), Laporan Zakat 2008, Kuala Lumpur: Pusat Pungutan Zakat Majlis Agama Islam Wilayah Persekutuan, p. 50; Jabatan Wakaf, Zakat dan Haji (2019), “Statistik Agihan Zakat," retrieved 20 ${ }^{\text {th }}$ March 2019, http://baitulmal.jawhar.gov.my/zkt_agihan_stat.php.
} 


\begin{tabular}{|c|c|c|c|c|c|c|c|c|}
\hline Johor & 16.8 & 6.68 & 11.37 & 5.43 & 0.13 & 32.07 & 1.79 & - \\
\hline \multicolumn{9}{|c|}{ Table 5: Zakat Disbursement by State in 2017 (in Million RM) ${ }^{23}$} \\
\hline State & Miskin & Faqir & 'Amil & Mu'allaf & $\begin{array}{c}\text { Ibn al- } \\
\text { Sabil }\end{array}$ & $\begin{array}{c}F i \\
\text { Sabilillah }\end{array}$ & Gharimin & $\overline{R i q a b}$ \\
\hline \multicolumn{9}{|l|}{ Federal } \\
\hline Territory & 101.90 & 88.35 & 39.20 & 14.00 & 0.34 & 210.44 & 6.04 & 2.12 \\
\hline Selangor & 205.74 & 88.14 & 94.64 & 45.13 & 0.25 & 112.26 & 47.82 & 22.56 \\
\hline $\begin{array}{l}\text { Penang } \\
\text { Negeri }\end{array}$ & 46.56 & 6.65 & 10.32 & 1.79 & 0.25 & 28.76 & 2.06 & - \\
\hline Sembilan & 34.13 & 0.75 & 11.50 & 7.55 & 0.23 & 33.40 & 1.81 & 18.21 \\
\hline Melaka & \multicolumn{8}{|c|}{ Not available } \\
\hline Pahang & 27.44 & 11.04 & 16.71 & 6.85 & 0.48 & 86.49 & 0.13 & 0.34 \\
\hline Sabah & 6.74 & 28.73 & 6.00 & 7.11 & 0.01 & 9.34 & 1.54 & 3.35 \\
\hline Kelantan & \multicolumn{2}{|c|}{110.67} & 24.32 & 1.79 & 0.01 & 41.56 & 0.04 & - \\
\hline Terengganu & 74.07 & 20.17 & 15.07 & 5.47 & 0.0005 & 66.26 & 1.87 & 0.85 \\
\hline Kedah & 69.81 & 12.07 & 11.15 & 1.40 & 0.16 & 57.40 & 0.08 & - \\
\hline Johor & 116.56 & 50.82 & 24.30 & 18.09 & 0.46 & 70.85 & 1.17 & - \\
\hline Sarawak & 3.78 & 9.63 & 7.14 & 2.56 & 0.003 & 25.63 & 0.01 & 0.03 \\
\hline Perak & \multicolumn{8}{|c|}{150.89 (for all recipients) } \\
\hline Perlis & \multicolumn{8}{|c|}{ Not available } \\
\hline
\end{tabular}

The above tables show that in the majority of states, the fund went mostly to four groups of recipients, namely faqir, miskin, 'amil and fi sabilillah. The former two grants reflect the allocation for poverty eradication, while the latter two signify the expenses for zakat management and other religious activities including Islamic education and State religious councils' spending. As the spending for all these groups has been increasing consistently along with the rising collection, it could be inferred that poverty eradication and financing Islamic institutions are the two aspects of greatest concern in zakat disbursal approaches.

Considering that Islamic institutions are the responsibility of the state religious councils to finance, it is unsurprising to find that most of the time, the allocation for $f i$ sabilillah and 'amil are among the highest in the majority of states. In the year 2000, as table 3 clearly shows, the provision for these groups is significantly higher than that for the miskin and faqir combined in the majority of states except three, namely Sabah, Terengganu and Kedah.

This pattern, however, changed in 2008 and 2017 when nine of the 14 states in the table 4 and at least eight out of 14 states in the table 5 distributed more of the fund towards poverty eradication. Such a pattern indicates the increasing concern of the zakat institution and religious authorities about the poverty problem in their respective states. On top of the higher allocation, various programs have been introduced under the heading of faqir and miskin for providing the recipients with financial and also non-financial support. Reflecting current practice by most states, JAWHAR through its manual of distribution has outlined a range of programs for poverty eradication. The manual outlines more than 20 programs for each faqir and miskin group, ranging from monthly allowances to business aid. Overall, the distribution approach has been shaped in such a way as to raise the living conditions of the recipients. ${ }^{24}$

From a broader development perspective, zakat has also been increasingly seen as a potential tool in poverty eradication, complementing other programs implemented by the government. The federal government, with regard to this aspect, since early 2000 has been gradually incorporating zakat into national economic plans, something that has never happened before. In 2001, for instance, zakat was included in the Malaysian Prospective Plan (2000-2010), a strategic plan indicating the economic

\footnotetext{
${ }^{23}$ Majlis Agama Islam Wilayah Persekutuan (2017), Laporan Tahunan MAIWP 2017, Kuala Lumpur: Majlis Agama Islam Wilayah Persekutuan, p.131; Lembaga Zakat Selangor (2017), Laporan Pengurusan Zakat Selangor 2017, Selangor: Lembaga Zakat Selangor, p.11; Jabatan Wakaf, Zakat dan Haji (2019), “Statistik Agihan Zakat," diakses 20 Mac 2019, http://baitulmal.jawhar.gov.my/zkt_agihan_stat.php.

${ }^{24}$ Jabatan Wakaf, Zakat dan Haji (2007), Manual Pengurusan Agihan Zakat, pp. 28-29.
} 
direction of the decade, so that it could be used for the development of Malay Muslims. ${ }^{25}$ This aspiration was again spelt out in the Ninth Malaysia Plan (2006-2010), a more specific economic program expanding the earlier one. The later plan stated that the fund should be directed towards poverty eradication, in the way that the zakat institution in many states is currently inclining. As for effective management, it was recommended that the Zakat Collection Center of Federal Territory (PPZ) should be replicated and corporate management adopted. ${ }^{26}$ This obviously shows recognition of the huge potential of the fund in the economy and provides a starting point for a more serious convergence between zakat and other economic institutions. The plan makes it explicit that zakat is increasingly a focus of governmental attention, which is undeniably good for its further advancement.

From the discussion, it could be concluded that the introduction of corporatization has been a revolutionizing factor leading to the increased collection and advancement of the zakat institution since the $1990 \mathrm{~s}$, and ultimately to greater fund distribution. Since the fund has the potential for poverty eradication, it can also be suggested that the institution should play a greater part in economic development beyond its original role as an expression of religious piety.

\section{Conclusion}

As has been self-evident throughout the discussion, there have been a significant advancement of zakat institution in the Malaysian post Islamic revivalism era. As early as the 1990s, the progress of the institution has revealed greater opportunities and increased potential for the fund. Since its use is compatible with Malaysia's economic development, zakat has finally been embraced as one of the tools for poverty eradication. With the majority of the population being Muslim Malays who are relatively weak economically, the government is expected to encourage greater allocation of zakat for poverty eradication. It seems that the attempt to improve the zakat institutions by the federal government has paid off, not merely by inducing Muslims to fulfil their religious obligation, but also by helping government to reduce poverty rate in the country.

\section{Acknowledgement}

We would like to acknowledge the financial support provided by Ministry of Higher Education for research grant no. FP064-2019A and the University of Malaya for research grant no. GPF005L-2019.

\section{References}

Ab Rahim Zakaria (2007), "Pengurusan Zakat Kontemporari," Jurnal Pengurusan JWZH, Vol. 1, No. $1,13-22$.

Abdul Aziz bin Muhammad (1993), Zakat and Rural Development in Malaysia, Kuala Lumpur: Berita Publishing.

Ahmad Fauzi bin Abdul Hamid (1998), Islamic Resurgence in the Periphery: A Study of Political Islam in Contemporary Malaysia with Special Reference to the Darul Arqam Movement, Doctoral Thesis, University of Newcastle Upon Tyne.

Ahmad Fauzi bin Abdul Hamid (2009), "Transnational Islam in Malaysia," in Transnational Islam in South and Southeast Asia; Movements, Networks and Conflicts Dynamics, USA: The National Bureau of Asian Research.

Ahmad Ibrahim (1965), Islamic Law in Malaya, Singapore: Malaysian Sociological Research Institute Ltd.

\footnotetext{
${ }^{25}$ The zakat fund was certainly included in the plan although it stipulation was rather indirect as it was understood that in many states the fund has been part of baitulmal resource which refers to any asset and fund managed by states religious councils. Government of Malaysia (2001), Third Outline Perspective Plan, Putrajaya: Government Printers, p. 98.

${ }^{26}$ Government of Malaysia (2006), Ninth Malaysia Plan 2006-2010, Putrajaya: The Economic Planning Unit, Prime Minister's Department, pp. $342-343$
} 
Aidit bin Ghazali (1991), "Zakat Administration in Malaysia," in Mohamed Ariff (ed.), The Islamic Voluntary Sector in Southeast Asia, Singapore: Institute of Southeast Asian Studies.

Aidit Ghazali (1988), Zakat, Satu Tinjauan, Petaling Jaya: IBS Buku.

Azhar Mohd Nasir (1999), Development of the Secular and Religious Taxation System in Peninsular Malaysia, Doctoral Thesis, University of Edinburgh.

Government of Malaysia (2001), Third Outline Perspective Plan, Putrajaya: Government Printers.

Government of Malaysia (2006), Ninth Malaysia Plan 2006-2010, Putrajaya: The Economic Planning Unit, Prime Minister's Department.

Hamayotsu, Kikue (2004), "Islamisation, Patronage and Political Ascendancy, The Politics and Business of Islam in Malaysia," in Edmund Terence Gomez (ed.), The State of Malaysia, Ethnicity, Equity and Reform, London: Routledge Curzon, 231-234.

Harian Metro (1992), "Pungutan Zakat WP Menjadi Contoh,” 21 January.

Jabatan Wakaf, Zakat dan Haji (2007), Manual Pengurusan Agihan Zakat, Putrajaya: JAWHAR.

Jabatan Wakaf, Zakat dan Haji (2019), "Statistik Agihan Zakat," retrieved 20 ${ }^{\text {th }}$ March 2019, http://baitulmal.jawhar.gov.my/zkt_agihan_stat.php.

Jomo K. Sundaram and Ahmad Shabery Cheek (1988), "The Politics of Malaysia's Islamic Resurgence," Third World Quarterly, Vol. 2, No. 10, 843-868.

Lembaga Zakat Selangor (2017), Laporan Pengurusan Zakat Selangor 2017, Selangor: Lembaga Zakat Selangor.

Majlis Agama Islam Wilayah Persekutuan (2017), Laporan Tahunan MAIWP 2017, Kuala Lumpur: Majlis Agama Islam Wilayah Persekutuan.

Mohamad Abu Bakar (1981), "Islamic Revivalism and Politics in Malaysia," Asian Survey, Vol. 10, No. 21, 1040-1059.

Muhammad Syukri Salleh (1994), "Islamization of State and Society: A Critical Comment," in Noraini Othman (ed.), Sharia Law and the Modern Nation State, Kuala Lumpur: Sister in Islam, 105-112.

Nagata, Judith (1980), "Religious Ideology and Social Change: The Islamic Revival in Malaysia," Pacific Affairs, Vol. 53, No. 3, 405-439.

Nagata, Judith (1982), "Islamic Revival and the Problem of Legitimacy Among Rural Religious Elites in Malaysia," Man, Vol. 1, No. 17, 42-57.

Pusat Pungutan Zakat - Majlis Agama Islam Wilayah Persekutuan (2001), Laporan Zakat 2000-2001, Kuala Lumpur: Pusat Pungutan Zakat - Majlis Agama Islam Wilayah Persekutuan.

Pusat Pungutan Zakat - Majlis Agama Islam Wilayah Persekutuan (2002), Laporan Zakat 2002, Kuala Lumpur: Pusat Pungutan Zakat - Majlis Agama Islam Wilayah Persekutuan.

Pusat Pungutan Zakat - Majlis Agama Islam Wilayah Persekutuan (2003), Laporan Zakat 2003, Kuala Lumpur: Pusat Pungutan Zakat - Majlis Agama Islam Wilayah Persekutuan.

Pusat Pungutan Zakat - Majlis Agama Islam Wilayah Persekutuan (2008), Laporan Zakat 2008, Kuala Lumpur: Pusat Pungutan Zakat - Majlis Agama Islam Wilayah Persekutuan. 
Pusat Pungutan Zakat - Majlis Agama Islam Wilayah Persekutuan (2011), Laporan Zakat 2011, Kuala Lumpur: Pusat Pungutan Zakat - Majlis Agama Islam Wilayah Persekutuan.

Pusat Pungutan Zakat - Majlis Agama Islam Wilayah Persekutuan (2016), Ringkasan Laporan Zakat 2016, Kuala Lumpur: Pusat Pungutan Zakat - Majlis Agama Islam Wilayah Persekutuan.

Roff, William R. (1998), "Pattern of Islamization in Malaysia, 1890s-1990s: Exemplars, Institutions and Vectors," Journal of Islamic Studies, Vol. 9, No. 2, 210-228.

The Sun (1996), "Special Agency to Collect Zakat From Firms," 16 October.

Yegar, Moshe (1979), Islam and Islamic Institutions in British Malaya: Policies and Implementation, The Hebrew University, Jerusalem: Magnes Press.

Zainah Anwar (1987), Islamic Revivalism in Malaysia: Dakwah Among Students, Petaling Jaya: Pelanduk Publication. 
Journal of Al-Tamaddun, Vol. 15 (2), 2020, $71-79$ 